\title{
Assessing learning in MOOCs through interactions between learners
}

Citation for published version (APA):

Brouns, F. M. R., \& Firssova, O. (2019). Assessing learning in MOOCs through interactions between learners. In S. D., D. J. B., \& E. R. (Eds.), Technology Enhanced Assessment: 21st International Conference, TEA 2018, Amsterdam, The Netherlands, December 10-11, 2018, Revised Selected Papers (pp. 42-54). Springer International Publishing AG. Communications in Computer and Information Science Vol. 1014 https://doi.org/10.1007/978-3-030-25264-9_4

\section{DOI:}

10.1007/978-3-030-25264-9_4

Document status and date:

Published: 13/07/2019

Document Version:

Early version, also known as pre-print

Document license:

CC BY-NC-SA

Please check the document version of this publication:

- A submitted manuscript is the version of the article upon submission and before peer-review. There can be important differences between the submitted version and the official published version of record. People interested in the research are advised to contact the author for the final version of the publication, or visit the DOI to the publisher's website.

- The final author version and the galley proof are versions of the publication after peer review.

- The final published version features the final layout of the paper including the volume, issue and page numbers.

Link to publication

\section{General rights}

Copyright and moral rights for the publications made accessible in the public portal are retained by the authors and/or other copyright owners and it is a condition of accessing publications that users recognise and abide by the legal requirements associated with these rights.

- Users may download and print one copy of any publication from the public portal for the purpose of private study or research.

- You may not further distribute the material or use it for any profit-making activity or commercial gain

- You may freely distribute the URL identifying the publication in the public portal.

If the publication is distributed under the terms of Article 25fa of the Dutch Copyright Act, indicated by the "Taverne" license above, please follow below link for the End User Agreement:

https://www.ou.nl/taverne-agreement

Take down policy

If you believe that this document breaches copyright please contact us at:

pure-support@ou.nl

providing details and we will investigate your claim.

Downloaded from https://research.ou.nl/ on date: 26 Apr. 2023 


\title{
Assessing learning in MOOCs through interactions between learners
}

\begin{abstract}
This paper presents a retrospective analysis of learning in a MOOC as reconstructed from the conversations that learners conducted in MOOC group forums while performing the course tasks. A mixed method approach was applied to analyse the quantity and the quality of these conversations. Two activity patterns were distinguished - in groups with higher activity levels, there were more individual contributions (posts) on more course themes and these contributions were broader spread throughout the course. In high activity groups there was also more interaction between participants, i.e., more questions, answers, explanations and elaborations. The presented study demonstrates how modeling interactions in group forums helps to elicit individual and emerging group knowledge construction and thus supports defining MOOC learning, informs MOOC design and provides insights on how assessing MOOC learning can be automated.
\end{abstract}

Keywords: assessing learning, learner interactions, knowledge building, text analysis, MOOC learning, mixed methods

\section{Theoretical framework}

After a decade of growth Massive Open Online Courses (MOOCs) may still be seen as a trend which develops next to the mainstream of the 21st century education. The growth is, however, spectacular. Major institutions in Higher Education including world top universities have already developed and offered open learning for altogether millions of learners all over the world. The body of knowledge on MOOCs, MOOC learners, MOOC design and MOOC technologies grows exponentially and the width of topics MOOC researchers are getting a better grip on is diverse.

The theoretical underpinnings of learning in massive online open education are, however, still under construction. MOOCs can be conceptualized, set up and run by their providers in a multitude of ways. MOOC participants enrolling in MOOCs pursue diverse goals, course completion being not necessarily among them [1]. Individual learners goals are known to vary and be susceptible to change dependent on the concrete (first) experiences and/or on other factors that may shape, hinder or re-shape the learning process [2]. 
The open access, "free" character and the absence of boundaries at curriculum level make learning in a MOOC and possible outcomes of this learning fuzzy, little predictable and thus little congruent with the mainstream curriculum-based learning. The question arises how using other mechanisms than compliance with pre-defined learning objectives or course completion can be used to define MOOC learning. This study addresses this question. Such a mechanism does not, however, need to be a separate effortful activity, an adjacent question is how (and to what extent) an assessing MOOC learning can be automated.

Individual learning is an internal process. Construction of knowledge, though, involves verbal interaction with others when learning outcomes are made explicit and communicated in some form, when there is collaborative effort involved [3-5] or when the interaction is a byproduct of individual learning activity, such as, for example, student seatwork [6]. Interactions that take place in online learning environments and are made "visible" with the help of technologies help to understand both what is learned and how it is done at both individual and group level [7]. The literature on technology enhanced learning in general and more specifically on computer mediated communication (CMC) and computer supported collaborative learning (CSCL) accumulated in the past decades of active use of computers for learning and teaching provides theoretical frames for understanding how exchanges in online learning environments contribute to learning and joint knowledge construction. This literature contains instrumentation for its analysis in the form of content coding schemes that are geared towards a particular instructional context or learning design [8-12].

The CSCL literature legacy can be used in the conceptualization, analysis and assessing MOOC learning when learners' active contributions to MOOC's environment in the form of posts, conversations and sharing experiences, ideas and artefacts are taken into account. While the first open online courses that followed the principles of learning in networks, the so called cMOOCs and the first massive knowledge consumption courses, the xMOOCs represented two distinct strands in open education movement, recent generations of MOOCs build upon the legacy of both strands combining in different constellations (elements of) "production and consumption" of knowledge with active and social learning elements [13-16].

This paper will zoom into learners' interactions in a MOOC environment as a way to establish the boundaries of and lay the ground for operationalizing MOOC learning. The next section first describes a framework for knowledge construction in online learning that combines aspects of individual learning with social learning and creation of (cultural) artefacts [5, 17].

\subsection{Knowledge building in online learning environments}

Various researchers have developed theories and models to explain how learners learn or how learning in communities might be facilitated. Models and frameworks like the Knowledge Building model by Scardamalia and Bereiter [18-20] or the often used Interaction Analysis model by Gunawardena, Lowe, \& Anderson [21] model contribu- 
tions of individual learners to shared knowledge construction. These models and frameworks are often based on underlying assumptions the researchers have on how learning occurs and therefore are specific and fine-grained. Such granularity limits applicability, in particular when effortful and time consuming detailed analysis of content or discourse is not feasible. As one of the aims of the current study was to look for a technology-based solution and analysis methods that potentially can be automated, an approach based on general principles of learning through interaction was taken as point of departure.

\subsection{Individual and group knowledge in an online learning environment}

Paavola and Hakkarainen (2005) combine three metaphors of learning in order to develop an emergent approach to understanding learning against the current societal trends and challenges: the acquisition metaphor (a monologue), the participation metaphor (a dialogue) and the knowledge-creation metaphor which sees learning as a trialogue, with interaction between learners through (cultural) artefacts they develop together.

In a way, Stahl $[4,5]$ connects these metaphors by conceptualizing the individual knowledge construction as a process embedded in a shared learning experience - as continuous interaction between personal and social learning. Individual knowledge is, in this view, externalized through public utterances and is constructed through discourse and interaction with others based on the exchange of utterances, clarifications, building on each other's input, resolving controversies and negotiating meanings. The model is illustrated in Fig. 1.

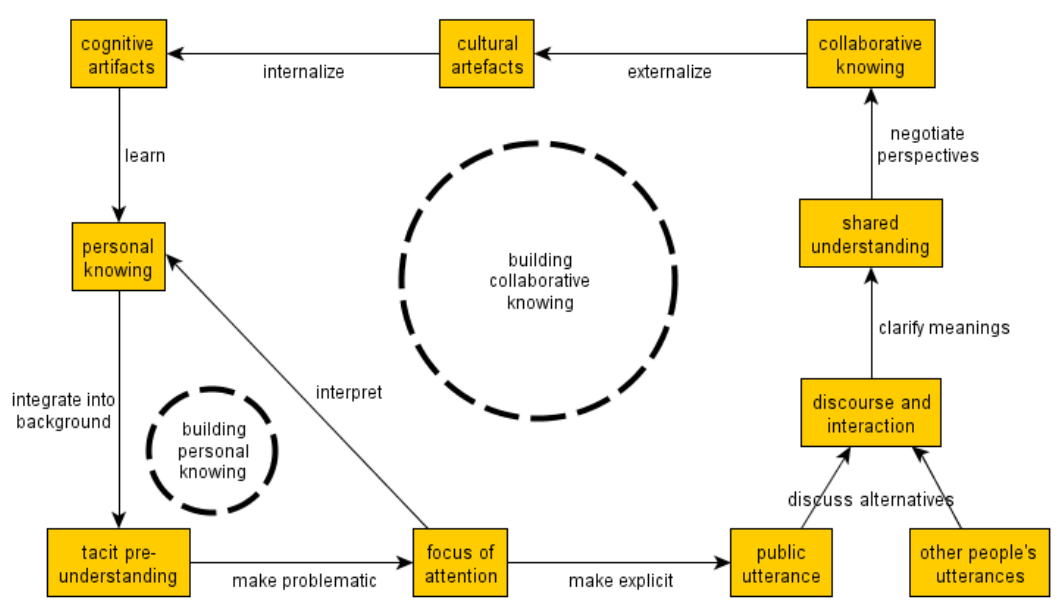

Fig. 1. Stahl's individual and shared cycle of knowledge exchange and construction, figure adjusted from [5] 
Externalizations take on various forms, such as teacher or learner monologue of dialogue between both, conversations between groups of learners, exchanges that involve few or many participants, remain superfluous or go deep, are anchored in sharing documents and artefacts or not.

Artefacts that are created and shared with others make it possible for all to engage in interaction and discourse around these artefacts, elaborate and build on the existing knowledge in order to construct new knowledge on both the individual and group level [17]. Analysis of utterances of individual learners and exchanges between learners together with analysis of artefacts can shed light on what is learned and the quality of this learning. At the same time such analysis can help to evaluate the richness of the environment in which individual and group conversations and learning through conversations occur [7, 22].

In an electronic learning environment learning becomes visible to others through exchanges between learners who can respond to each other in real time (i.e., through chat) and asynchronously (i.e., through discussion boards or social media). Learning is thus also visible for those who are not directly involved in conversations but might benefit from reading available exchanges and reflecting on them at a later moment. "Invisible" learning of these silent learners might in its turn become visible if they eventually join an on-going conversation or start a new one and thus contribute to exchanges that act as instantiations and at the same time as both sources and triggers of individual and collaborative knowing [5]. Thus, individual learning as an internal monologue and social interaction as a dialogue transform into collaborative learning and knowledge creation [17].

\subsection{Modelling personal and shared knowledge construction through discourse in a shared online learning environment}

In his model Stahl demonstrates the interdependence of individual and collaborative knowledge building without further specifying kinds of knowledge and actors involved. Garrison, Anderson and Archer [23] provide such a specification defining cognitive, social and teaching presence as essential elements or constituent parts of the learning process in an online environment. According to Garrison et al [23], cognitive presence manifests itself in articulations of event triggers, exploration of ideas through sustained information exchange and formulating new ideas. Social presence refers to learners presenting themselves and communicating with others in order to connect, initiate and maintain interaction, and/or build up a relationship, increase or maintain trust. Social presence allows participants in an online exchange to develop a sense of belonging in a community and establish or strengthen a personal identity. The sense of belonging is in its turn reported to be positively associated with motivation, satisfaction, performance and the degree of perceived learning The third element, teaching presence is related to the design of the educational experience and facilitation of the learning process. Garrison and colleagues [23] speak of it as 'a means to an end', referring to the function of teaching presence - to support and enhance cognitive and social presence in the learning environment by promoting meaningful interaction [23, 24]. 


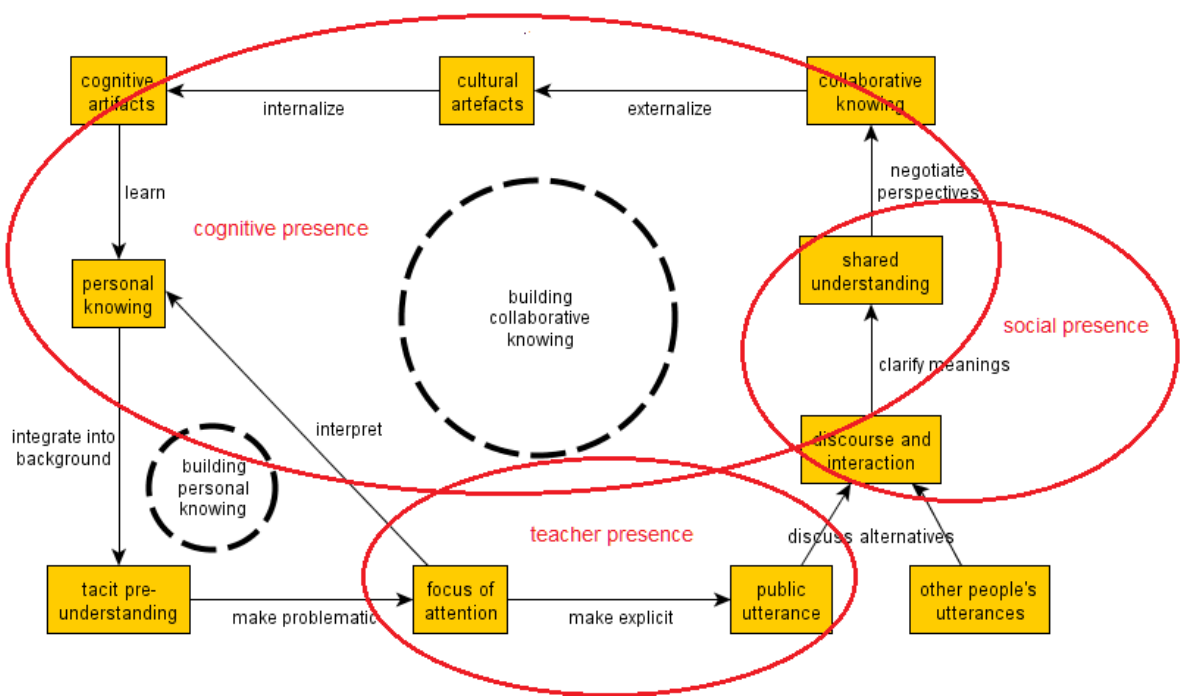

Fig. 2. Specifying the type of knowledge (and presence) involved according to Garrison [23] in the model of individual and shared cycle of knowledge exchange and construction according to Stahl [5]

Combining the model of individual versus collaborate knowing development through discourse [5] with a types of knowledge specifications model [23] allows to frame the knowledge exchange processes in general terms yet with sufficient specificity that assessment and evaluation require and thus to define learning through interaction. Fig. 2 visualises a possible relation between the two models.

In the study described below, this combined framework was applied to analyse interactions between MOOC participants in order to define MOOC learning. Given the benefits shown in other studies from combining quantitative and qualitative research $[9,25]$, a mixed-method approach was used to answer the formulated research questions.

\section{Methodology}

\subsection{Context}

The context of this study is a MOOC on the topic of blended learning. The MOOC targeted teachers interested in using blended learning principles and tooling in course design internet technologies. The MOOC was offered free of charge, an optional certified track required a fee and required participants to maintain a portfolio and submit a final assignment (a blueprint of course design or redesign).

The MOOC lasted 8 weeks and covered 5 different topics related to the use of internet technology for course design, assessment, communication, individual and collaborative learning and the role of a teacher as designer of learning activities. 
The first week combined an introduction to the topic with personal introductions as a way for learners to get to know each other. The final week included a reflection on own progress and on the general topic of the MOOC.

All topics followed the same structure. The week started with an orientation on a topic through self-study to be followed by an expert introduction of the topic presented in an interactive live online video session. The expert also gave general feedback on the contributions to the orientation assignment, responded to questions and posts in the forum or posed in the chat during the online session and elaborated on subsequent tasks. Additional readings were available for those interested in in-depth learning.

Collaboration and exchanges between participants were stimulated by task design that anchored tasks in professional contexts relevant for participants and invited participants to share assignments with others participants, and give each other feedback. To streamline this process, 1181 participants were randomly divided into 13 subgroups, each with access to a dedicated discussion forum next to the general forum. Group size was on average 90, ranging from 64 to 119 [15].

Participants were informed that the MOOC was part of ongoing research and that their participation and contributions in the MOOC would be tracked. By registering for and enrolling in the MOOC, participants agreed to their data being used for research. Participants were informed that participation remained voluntary and that they could withdraw at any time.

\subsection{Data analysis}

Participant contributions to discussion forums was analysed in two ways. First, a quantitative descriptive analysis was made of participation in the group forums of all 13 groups. This entailed a calculation of frequency of messages sent, number of threads, and thread length.

Because the quantitative analyses seemed to suggest difference in posting behaviour between groups a systematic text analysis method [26-28] was applied to determine whether this quantitative difference was also reflected in the type of messages posted. Therefore a selection of groups was made to provide sufficient data for the required analyses. Selection was based on the total number of messages in the discussion forum and the number of messages related to each of the 16 different assignments.

Three groups with the least exchanges and three groups with the most exchanges were selected for the systematic text analysis. In the remainder of this paper these are referred to as 'high activity' and 'low activity' groups.

NVivo $10^{1}$ was used to analyze the forum messages. Before starting with coding an initial exploration of the forum messages was made based on word frequency and word clouds to inform the coding categories.

For text analysis purposes, messages of each of the discussion forums for the 6 groups were exported from the database in CSV format and imported into an Excel sheet. This Excel sheet was then imported into NVivo, marking the column containing the message text as NVivo codable. Fields that could identify individual persons were

${ }^{1}$ http://www.qsrinternational.com/ 
excluded from analysis. A complete individual post (text message) was used as the unit of analysis. More than one category could be used to code the message.

Conceptual frameworks by Stahl [5] and Garrison and colleagues [23] and the grounded theory approach [29] was used to model learners' interactions. A coding scheme was developed in several iterations by the two researchers who performed the coding. The final model included the categories as shown in Table 1. The table provides the definition of the coding category and indicates between brackets the type of presence. Examples of coded utterances are provided to illustrated the categories that constitute the model.

Messages of three 'high activity' and three 'low activity' groups were analyzed to compare if groups that posted more messages also showed different interaction patterns and/or differed in the nature of their conversations. A chi-square analyses were performed to check if interaction level had an effect on the distribution of type of messages.

Table 1. Coding categories of the forum messages, type of presence and example of posts in the forum

\begin{tabular}{|c|c|c|}
\hline $\begin{array}{l}\text { Category (type of pres- } \\
\text { ence) }\end{array}$ & Defin & aple \\
\hline $\begin{array}{l}\text { Personal introduction (So- } \\
\text { cial presence } \\
\text { triggered by instruction - } \\
\text { teacher presence) }\end{array}$ & $\begin{array}{l}\text { Participants introduce } \\
\text { themselves, provide some } \\
\text { background and indicate } \\
\text { their learning needs and } \\
\text { goals for participating in } \\
\text { the MOOC. }\end{array}$ & $\begin{array}{l}\text { My name is E. A... and I } \\
\text { participate in this MOOC } \\
\text { out of curiosity about the } \\
\text { possibilities of adapting } \\
\text { education to the } 21 \text { st cen- } \\
\text { tury. ... }\end{array}$ \\
\hline $\begin{array}{l}\text { Social interaction (Social } \\
\text { presence) }\end{array}$ & $\begin{array}{l}\text { Any message that was not } \\
\text { related to content or as- } \\
\text { signments of the MOOC } \\
\text { but consisted of social ex- } \\
\text { change. }\end{array}$ & $\begin{array}{l}\text {... Nice to read your intro- } \\
\text { duction, in which I see } \\
\text { similarities with my own } \\
\text { experiences. ... }\end{array}$ \\
\hline $\begin{array}{l}\text { Knowledge telling (Cog- } \\
\text { nitive presence triggered } \\
\text { by instruction - teacher } \\
\text { presence) }\end{array}$ & $\begin{array}{l}\text { The participant presents } \\
\text { facts, provides descrip- } \\
\text { tions, reproducing infor- } \\
\text { mation, knowledge with- } \\
\text { out elaborating. }\end{array}$ & $\begin{array}{l}\text {... Within our faculty we } \\
\text { use Blackboard, by many } \\
\text { this ELE is only used to } \\
\text { post slides and articles, } \\
\text { but there is a small num- } \\
\text { ber of teachers who also } \\
\text { use other available tools } \\
\text { in education. }\end{array}$ \\
\hline $\begin{array}{l}\text { Elaborating on knowledge } \\
\text { (Cognitive presence) }\end{array}$ & $\begin{array}{l}\text { The participant not only } \\
\text { reproduces facts, infor- } \\
\text { mation, knowledge, but } \\
\text { elaborates on it by provid- } \\
\text { ing: } \\
\text { - examples from own ex- } \\
\text { periences; } \\
\text { - examples from practice; }\end{array}$ & $\begin{array}{l}\text { When I consider my first } \\
\text { learning experiences with } \\
\text { MOOCs, I find this way } \\
\text { of learning very powerful. } \\
\text { Interesting reflection } \\
\text { questions are asked (such } \\
\text { as this assignment) and } \\
\text { there is mutual feedback }\end{array}$ \\
\hline
\end{tabular}




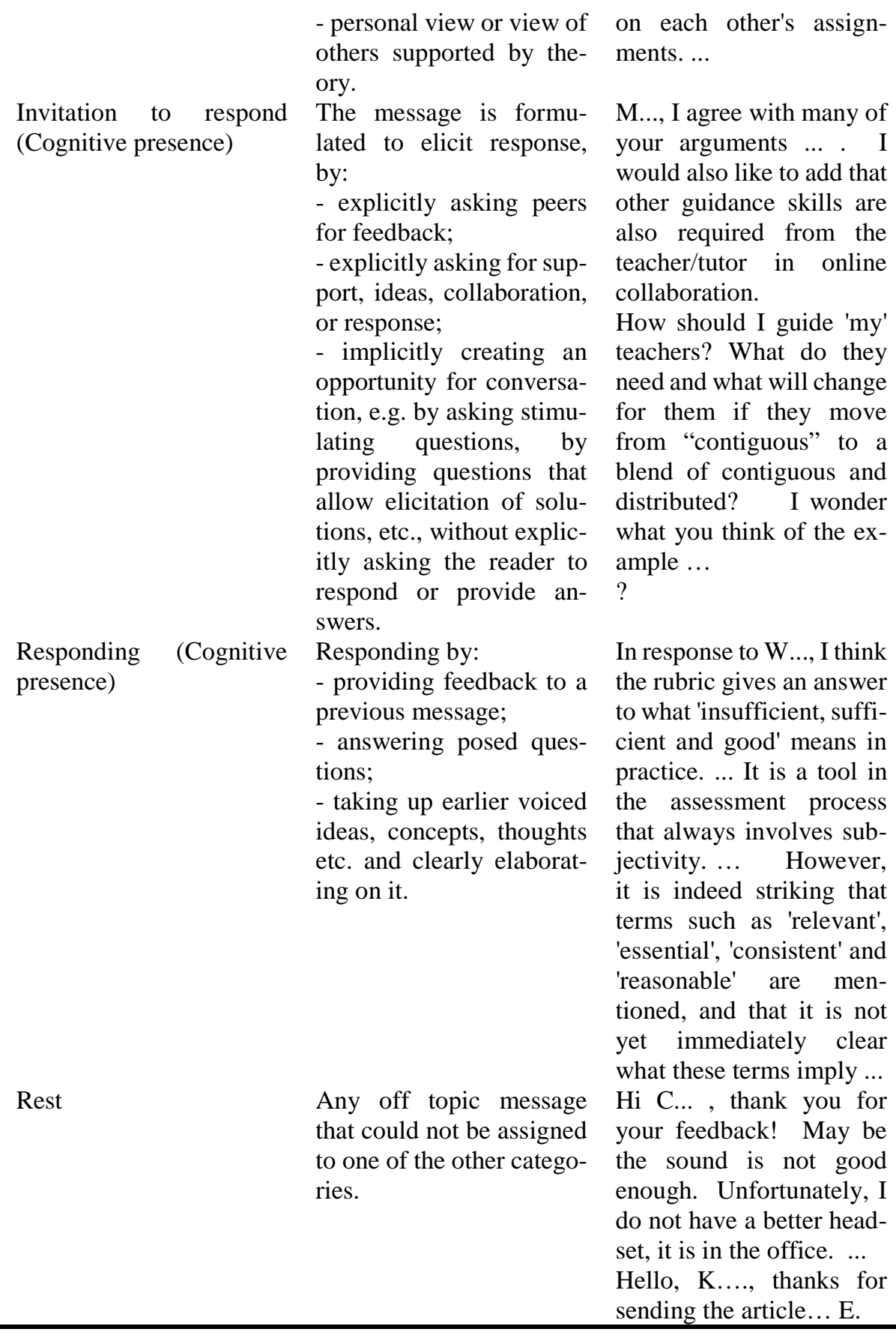




\section{$3 \quad$ Results}

\subsection{Interaction in group forums: visible patterns}

Participants of the 6 groups placed in total 1442 messages, grouped in 846 threads with an average thread length of 1.6. As shown in Fig. 3, by far the most messages (34\%) were placed in week 1 , while the number of messages for the other topics was lower but still fairly consistent, although the number of messages seemed to decrease in week 6.

Overall, only half of participants engaged in the discussion forums. Moreover, two patterns could be observed in the activity in these forums: 'high activity' groups in which participants posted more messages (see Table 2) and remained active, i.e., kept posting messages for each of the assignments during the whole of the MOOC, and 'low activity' groups in which participants posted fewer messages and the number of messages declined with MOOC progression. Fig. 3 illustrates the observed trend.

Table 2. Frequency of posting in high and low activity groups

\begin{tabular}{lcc}
\hline & High activity & Low activity \\
\hline Total number of participants & 283 & 240 \\
Total number unique participants posting & 150 & 112 \\
Total number of threads & 555 & 291 \\
Total number of messages & 1049 & 393 \\
Average number of threads per active poster & 3.7 & 2.6 \\
Average number of messages per active poster & 7.1 & 3.6 \\
\hline
\end{tabular}

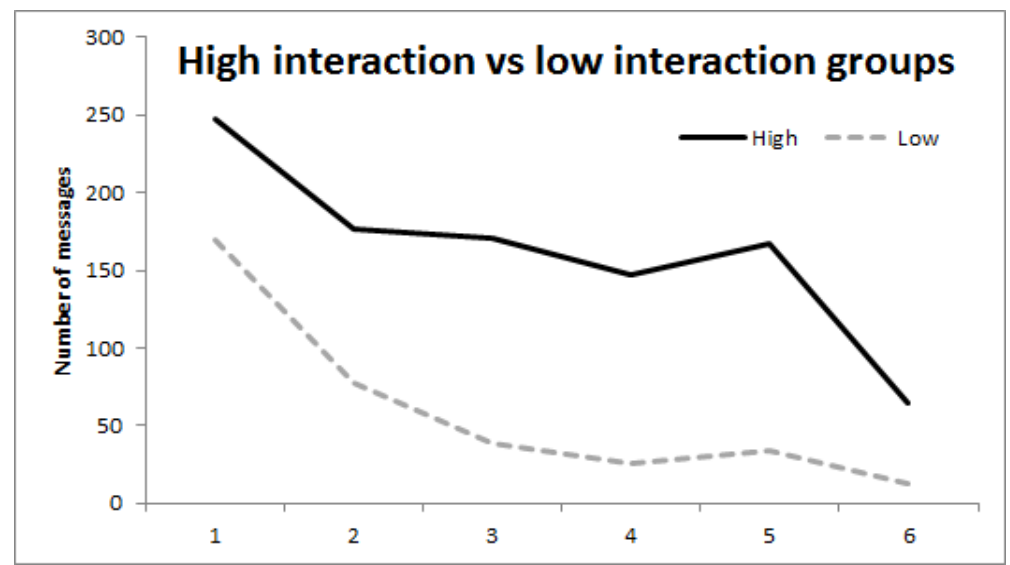

Fig. 3. Number of messages per topic/week for 3 'high activity' groups and 3 'low activity' groups 
Table 3 presents an overview of the type of interactions in both high and low activity groups. Although all types of messages are present in each group, the interaction patterns differ $(\chi 2(6)=96.14, p<.001$, Cramer $\mathrm{V} .243)$. In 'low activity' groups 'Knowledge telling' category is a dominant category and 'Personal introduction' is the second best represented category. Both these categories are associated with teacher presence as they represent contributions that result from instructional prompts. In 'high activity' groups, statements from the categories 'Invitation to respond' and 'Responding' have the highest frequency. Both categories are associated with cognitive presence and are indicative of a participation metaphor or dialogical learning [17, 23].

Table 3. Distribution of type of messages in high and low activity groups (\% within group)

\begin{tabular}{lccc}
\hline Type of message & $\begin{array}{c}\text { High activity } \\
\%\end{array}$ & $\begin{array}{c}\text { Low activity } \\
\%\end{array}$ & $\begin{array}{c}\text { Both groups } \\
\%\end{array}$ \\
\hline Personal introduction & 11.2 & $\mathbf{2 1 . 8}$ & 13.9 \\
Social interaction & 5.4 & 2.2 & 4.5 \\
Knowledge telling & 17.6 & $\mathbf{3 3 . 0}$ & $\mathbf{2 1 . 6}$ \\
Elaborating on knowledge & 13.3 & 7.9 & 11.9 \\
Invitation to respond & $\mathbf{2 0 . 5}$ & 15.1 & 15.1 \\
Responding & $\mathbf{2 8 . 8}$ & 16.7 & $\mathbf{2 5 . 7}$ \\
Rest & $\mathbf{3 . 1}$ & 3.3 & 3.2 \\
\hline
\end{tabular}

While there was not a lot of difference in the average number of words per message between the groups (100 words and 97 words for high and low respectively), the number of words used for the various types of messages differs. In the 'low activity' groups, 'Knowledge telling' messages also contained most words, while 'high activity' groups used more words to elaborate on knowledge and to invite interaction (Table 4).

Table 4. Distribution of the number of words used in the various types of messages, expressed as percentage of total number of words used within the group

\begin{tabular}{lcc}
\hline Type of message & \% in 'high activity’ & \% in ‘low activity' \\
\hline Personal introduction & 14.0 & $\mathbf{2 0 . 8}$ \\
Social interaction & 2.3 & 0.9 \\
Knowledge telling & 22.1 & $\mathbf{3 4 . 3}$ \\
Elaborating on knowledge & $\mathbf{3 0 . 7}$ & 18.4 \\
Invitation to respond & 24.8 & 16.1 \\
Responding & $\mathbf{3 0 . 1}$ & 18.9 \\
Rest & 1.0 & 1.9 \\
\hline
\end{tabular}

\section{Conclusion}

In this study analysis of learners' interactions in group discussion forums was undertaken in order to define learning in a MOOC through these interactions and answer the question whether MOOC learning can be assessed based on the analysis of interactions between MOOC learners. 
The approach taken - combining quantitative and qualitative methods [30] - proved valuable in defining an analytical framework and applying it to describe all interactions between MOOC participants that took place in the discussion forums.

According to these analyses, two distinct patterns could be discerned. These patterns can be described in line with the two theoretical frameworks applied - Stahl's model of individual and collective knowing [5] and Garrison's community of inquiry model [23]. Interactive learning environments (in this particular case, group discussion forums) may be both rich or poor in terms of visible individual and collaborative knowledge construction and in terms of social and cognitive presence.

Like in other studies, merely providing communication or collaboration tools does not guarantee that the participants will make use of them nor that they will engage in meaningful interaction. Recent studies showed that in MOOCs only a minor percentage of participants tend to use forums. On the other hand, whenever learners engage in interaction, through media as a part of the course activities, it can result in increased course-completion as a proxy of learning [22, 31-33]. This study demonstrated that active forum use can also be seen as a proxy of learning when learning is associated with richer cognitive presence and social presence related to it.

This study confirmed that MOOC participants differ in the level of interaction. Social presence and cognitive presence were manifested in both the 'high activity' and 'low activity' groups. Both were triggered by prompts in the learning environment due to the design of the learning activity and assignments (teacher presence). However, in 'low activity' groups social presence was practically limited to the prompted activity of personal introductions while in 'high activity' groups social presence manifested itself in on-going exchanges throughout the course. Social interaction was related to cognitive presence that manifested itself in exchanges between learners, invitations to respond and responding. Cognitive presence in 'low activity' groups was limited to knowledge telling which in its turn was prompted by instruction (teacher presence). In 'high activity' groups there was stronger and more explicit cognitive presence in the form of knowledge elaboration and interaction with others.

In terms of Stahl, we can assume that in 'high activity' groups both individual knowledge construction (individual knowing) resulting from knowledge elaboration and knowledge based exchanges with other learners, and collective knowledge construction (collective knowing) took place. The learning environment in these 'high activity' groups can be defined as learning-rich compared to the environment in the 'low activity' groups.

Based on the conducted analyses it can be assumed that the learning environment of a massive open online course that supports and stimulates knowledge exchange can make the knowledge-under-development of individual learners explicit. Instantiations of such knowledge exchanges provide insights in the quality of learning.

From MOOC design perspective, this study provided an argument in favour of active learning designs in which exchanges between learning are stimulated and orchestrated [22] as such interactions cannot be expected to emerge in open online environment by default [34] but result from a combination of factors, with learning design being an important one. As Laurillard [7, 22] explains, effective learning designs should stimu- 
late learners to become active and engaged, not only by providing sufficient and stimulating learning activities and assignments but also by stimulating interaction through various roles a learner can take on.

From the MOOC learning assessment perspective, the quantity of exchanges and an easy-to-perform classification of these exchanges can be taken as a point of departure in designing learning analytics and (semi-) automated assessment modules to act as indicators that knowledge construction takes place and it is worthwhile to look further into its quality. The combination of quantitative and qualitative methodologies has been shown to be valuable and therefore it is advisable in future research to use this combination of methodology to provide sufficient quality of the measurements and provide meaningful feedback to teacher and learner [9, 26, 27, 35].

While learning in massive open online courses may remain less plannable and to a less extent predictable than other forms of learning, including online learning, understanding that designing and supporting interactions enhances learning and makes it visible and to a certain extent accountable, increases sustainability of open learning.

\section{References}

1. Henderikx, M., Kreijns, K., Kalz, M.: To Change or Not to Change? That's the Question... On MOOC-Success, Barriers and Their Implications. In: Kloos, C.D., Jermann, P., Pérez-Sanagustin, M., Seaton, D.T., White, S. (eds.) Digital Education: Out to the World and Back to the Campus, Madrid, Spain (2017). doi: doi:10.1007/9783-319-59044-8_25

2. Henderikx, M.A., Kreijns, K., Kalz, M.: Refining success and dropout in massive open online courses based on the intention-behavior gap. Distance Education 38, 353368 (2017). doi: 10.1080/01587919.2017.1369006

3. Dillenbourg, P.: What do you mean by collaborative learning? In: Dillenbourg, P. (ed.) Collaborative-learning: Cognitive and Computational Approaches, pp. 1-19. Elsevier, Oxford, United Kingdom (1999)

4. Stahl, G.: Collaborative information environments to support knowledge construction by communities. AI \& Society 14, 71-97 (2000). doi: 10.1007/bf01206129 5. Stahl, G.: Group cognition: Computer support for building collaborative knowledge. MIT Press, Cambridge, MA (2006)

6. Nijland, F.J.: Mirroring interaction. An exploratory study into student interaction in independent working. Tilburg University, the Netherlands (2011). doi:

7. Laurillard, D.: Rethinking university teaching: A conversational framework for the effective use of learning technologies RoutledgeFalmer, London, United Kingdom (2002)

8. Veldhuis-Diermanse, A.E., Biemans, H.J.A., Mulder, M., Mahdizadeh, H.: Analysing Learning Processes and Quality of Knowledge Construction in Networked Learning. The Journal of Agricultural Education and Extension 12, 41-57 (2006). doi: 10.1080/13892240600740894 
9. Schrire, S.: Knowledge building in asynchronous discussion groups: Going beyond quantitative analysis. Computers \& Education 46, 49-70 (2006). doi: http://dx.doi.org/10.1016/j.compedu.2005.04.006

10. Strijbos, J.-W., Martens, R.L., Prins, F.J., Jochems, W.M.G.: Content analysis: What are they talking about? Computers \& Education 46, 29-48 (2006). doi: https://doi.org/10.1016/j.compedu.2005.04.002

11. Weinberger, A., Fischer, F.: A framework to analyze argumentative knowledge construction in computer-supported collaborative learning. Computers \& Education 46, 71-95 (2006). doi: http://dx.doi.org/10.1016/j.compedu.2005.04.003

12. De Wever, B., Schellens, T., Valcke, M., Van Keer, H.: Content analysis schemes to analyze transcripts of online asynchronous discussion groups: A review. Computers \& Education 46, 6-28 (2006). doi: http://dx.doi.org/10.1016/j.compedu.2005.04.005

13. Kalz, M., Specht, M.: If MOOCS are the answer, did we ask the right questions? Implications for the design of large-scale online-courses. Maastricht School of Management (2013)

14. Berlanga, A.J., Kalz, M., Stoyanov, S., Van Rosmalen, P., Smithies, A., Braidman, I.: Using Language Technologies to Diagnose Learner's Conceptual Development. In: Proceedings of the 9th IEEE International Conference on Advanced Learning Technologies (ICALT2009) pp. 669-673. IEEE, (2009)

15. Rubens, W., Kalz, M., Koper, R.: Improving The Learning Design of Massive Open Online Courses. The Turkish Online Journal of Educational Technology 13, 71 80 (2014)

16. removed for anonymous review

17. Paavola, S., Hakkarainen, K.: The Knowledge Creation Metaphor - An Emergent Epistemological Approach to Learning. Science \& Education 14, 535-557 (2005). doi: 10.1007/s11191-004-5157-0

18. Scardamalia, M., Bereiter, C.: A Brief History of Knowledge Building. Canadian Journal of Learning and Technology / La revue canadienne de l'apprentissage et de la technologie (2010). doi: 10.21432/t2859m

19. Hewitt, J., Scardamalia, M.: Design Principles for Distributed Knowledge Building Processes. Educational Psychology Review 10, $75-96$ (1998). doi: 10.1023/a:1022810231840

20. Cacciamani, S., Perrucci, V., Khanlari, A.: Conversational functions for knowledge building communities: a coding scheme for online interactions. Educational Technology Research and Development 1 - 18 (2018). doi: 10.1007/s11423-018-9621$\mathrm{y}$

21. Gunawardena, C.N., Lowe, C.A., Anderson, T.: Analysis of a global online debate and the development of an Interaction Analysis Model for examining social construction of knowledge in computer conferencing. Journal of Educational Computing Research 17, 397-431 (1997). doi: 10.2190/7MQV-X9UJ-C7Q3-NRAG

22. Laurillard, D.: The pedagogical challenges to collaborative technologies. Computer Supported Learning 4, 5 - 20 (2009). doi: https://doi.org/10.1007/s11412008-9056-2 
23. Garrison, D.R., Anderson, T., Archer, W.: Critical thinking, cognitive presence, and computer conferencing in distance education. American Journal of Distance Education 15, 7-23 (2001). doi: 10.1080/08923640109527071

24. Joksimović, S., Gašević, D., Kovanović, V., Riecke, B.E., Hatala, M.: Social presence in online discussions as a process predictor of academic performance. Journal of Computer Assisted Learning 31, 638-654 (2015). doi: 10.1111/jcal.12107

25. Pena-Shaff, J.B., Nicholls, C.: Analyzing student interactions and meaning construction in computer bulletin board discussions. Computers \& Education 42, 243265 (2004). doi: http://dx.doi.org/10.1016/j.compedu.2003.08.003

26. Geisler, C.: Coding for Language Complexity: The Interplay Among Methodological Commitments, Tools, and Workflow in Writing Research. Written Communication 35, 215-249 (2018). doi: 10.1177/0741088317748590

27. Geisler, C.: Analyzing Streams of Language: Twelve Steps to the Systematic Coding of Text, Talk, and Other Verbal Data. Pearson Longman, N. Y. (2004)

28. Geisler, C.: Current and emerging methods in the rhetorical analysis of texts Introduction: Toward an integrated approach. Journal of Writing Research 7, 417-424 (2016). doi: 10.17239/jowr-2016.07.03.05

29. Harry, B., Sturges, K.M., Klingner, J.K.: Mapping the Process: An Exemplar of Process and Challenge in Grounded Theory Analysis. Educational Researcher 34, 3 13 (2005)

30. Rourke, L., Anderson, T.: Validity in quantitative content analysis. Educational Technology Research and Development 52, 5 - 18 (2004). doi: 10.1007/bf02504769

31. Alario-Hoyos, C., Perez-Sanagustin, M., Delgado-Kloos, C., Parada G, H.A., Munoz-Organero, M.: Delving into Participants' Profiles and Use of Social Tools in MOOCs. IEEE Transactions on Learning Technologies 7, 260 - 266 (2014). doi: 10.1109/TLT.2014.2311807

32. Huang, J., Dasgupta, A., Ghosh, A., Manning, J., Sanders, M.: Superposter behavior in MOOC forums. Proceedings of the first ACM conference on Learning @ scale conference, pp. 117-126. ACM, Atlanta, Georgia, USA (2014). doi: $10.1145 / 2556325.2566249$

33. removed for anonymous review

34. Sloep, P., Kester, L.: From Lurker to Active Participant. In: Koper, R. (ed.) Learning Network Services for Professional Development, pp. 17-25. Springer Verlag, Berlin, Germany (2009)

35. Rosé, C., Wang, Y.-C., Cui, Y., Arguello, J., Stegmann, K., Weinberger, A., Fischer, F.: Analyzing collaborative learning processes automatically: Exploiting the advances of computational linguistics in computer-supported collaborative learning. Computer Supported Learning 3, 237-271 (2008). doi: 10.1007/s11412-007-9034-0 